\title{
The Two Major Phosphoproteins in Growth Cones Are Probably Identical to Two Protein Kinase C Substrates Correlated with Persistence of Long-Term Potentiation
}

\author{
Robert B. Nelson, ${ }^{1, a}$ David J. Linden, ${ }^{1}$ Carolyn Hyman, ${ }^{2}$ Karl H. Pfenninger, ${ }^{3}$ and Aryeh Routtenberg, ${ }^{1}$ \\ ${ }^{1}$ Cresap Neuroscience Laboratory, Northwestern University, Evanston, Illinois 60201, 2Department of Cellular Biology, New \\ York University Medical Center, New York, New York 10016, and ${ }^{3}$ Department of Cellular and Structural Biology, \\ University of Colorado, Denver, Colorado 80262
}

Regulation of neural protein kinase $\mathrm{C}$ (PKC) activity appears to directly affect the persistence of long-term potentiation (LTP; Akers and Routtenberg, 1985; Lovinger et al., 1985, 1986, 1987; Routtenberg et al., 1985, 1986; Akers et al., 1986; Linden et al., 1987), a model of neural plasticity (Bliss and Lomo, 1973). In addition, the in vitro phosphorylation of a brain-specific PKC substrate, protein F1 ( $M_{\mathrm{r}} 47 \mathrm{kDa}$, pl 4.5), has been directly correlated with persistence of LTP (Lovinger et al., 1986). Because PKC has been implicated in neurite outgrowth and is present at high levels in growth cone-rich areas of fetal brain, we investigated and characterized PKC substrates in a preparation of isolated nerve growth cone fragments from fetal rat brain and compared them with PKC substrates found in adult rat hippocampus. Four major proteins in the growth cone preparation showed endogenous phosphorylation levels at least 10-fold greater than any other phosphoproteins. Three of these 4 phosphoproteins, termed pp40, pp46, and pp80 (Katz et al., 1985), were phosphorylated by exogenous PKC in a dose-dependent manner, indicating that PKC activity might be of particular importance relative to other kinases in growth cone function. The 2 most highly labeled PKC substrates, pp46 and pp80, comigrated on 2-dimensional gels with the adult hippocampal proteins $F 1$ and " $80 \mathrm{k}$ " $(M, 78-80 \mathrm{kDa}, \mathrm{pl} \mathrm{4.0})$, respectively. In addition, similarities in charge heterogeneity, 2-dimensional phosphopeptide maps, and increased phosphorylation in the presence of exogenous PKC or PKC stimulators suggest that protein $F 1$ and $80 \mathrm{k}$ are highly homologous to, if not identical to, pp46 and pp80, respectively. The relationship of $80 \mathrm{k}$ phosphorylation to persistence of LTP has been masked previously by its comigration on 1-dimensional SDS gels with the major phosphoproteins

Received June 18, 1987; revised May 25, 1988; accepted June 3, 1988

This research was supported by a grant from the National Institutes of Health (MH 25281-13 to A.R.), the National Science Foundation (BNS86-44972 to K.H.P.), and the Air Force (AFSOR87-0042 to A.R.). R.B.N. is a National Research Service Award recipient (1 F31 DAO5254), D.J.L. is an Air Force Laboratory Graduate Fellowship recipient (S-789-000-001), and C.H. is the recipient of a Muscular Dystrophy Association postdoctoral fellowship. We wish to thank Dr. Shew Chan for providing purified protein Fl and Dr. Kentaro Murakami for providing purified protein kinase $\mathrm{C}$.

Correspondence should be addressed to Aryeh Routtenberg, Northwestern University, Cresap Neuroscience Laboratory, 2021 Sheridan Road, Room 311, Evanston, IL 60208.

"Present address: The DuPont Company, Neuroscience Group, Experimental Station, E400/3442, Wilmington, DE 19898.

Copyright (C) 1989 Society for Neuroscience 0270-6474/89/020381-09\$02.00/0 synapsin la and lb. Quantitative analysis of in vitro labeled phosphoproteins separated by 2-dimensional gel electrophoresis revealed that this second major neural PKC substrate, along with protein $\mathrm{F} 1$, was directly correlated with persistence of LTP induced in vivo. The present results suggest that PKC and its substrates play a central role in growth cone function and that this protein kinase system may underlie both normal neurite growth in developing brain and neural plasticity at adult synapses (Routtenberg, 1985, 1986; Pfenninger, 1986; Pfenninger et al., 1986).

Protein kinase C (PKC; Kikkawa et al., 1982), a $\mathrm{Ca}^{2+}$ and phospholipid-dependent kinase, appears to be translocated from a cytosolic to a membrane-associated state following the induction of long-term potentiation (LTP) in the intact hippocampus of adult rats (Akers et al., 1986). Recent evidence has suggested that PKC may directly regulate persistence of LTP: intrahippocampal injection of PKC stimulators, such as phorbol esters or oleic acid, increase the persistence of LTP (Routtenberg et al., 1986; Linden et al., 1987); conversely, the administration of the PKC inhibitors polymyxin $\mathrm{B}$, melittin, or $\mathrm{H}-7$ all block the maintenance of LTP (Lovinger et al., 1987)

PKC has also been linked to neural development: it copurifies with, and may be identical to, the phorbol ester receptor (Niedel ct al., 1983) which has been found in high concentrations in growth cone-rich regions of the developing nervous system (Nagle et al., 1981; Murphy et al., 1983). Moreover, phorbol esters, which both activate and translocate PKC (Castagna et al., 1982; Kraft and Anderson, 1983), are able to induce neurite outgrowth in cultured explants (Hsu et al., 1984; Natyzak and Laskin, 1984).

Because we have previously found that the phosphorylation of a brain-specific PKC substrate, protein F1, is directly correlated with persistence of LTP in adult rats, we were interested in whether PKC might phosphorylate the same substrates in both adult hippocampus and in nerve growth cones from fetal rat brain. Substrates for $\mathrm{Ca}^{2+}$-dependent kinases have been reported to be prominent in a purified fraction of "growth cone particles" (GCPs; Pfenninger et al., 1983; Katz et al., 1985; Hyman and Pfenninger, 1987). Using 2-dimensional gel electrophoresis and 2-dimensional phosphopcptide mapping, we compared the properties of phosphoproteins in a synaptosomeenriched fraction of adult hippocampal formation with those present in GCPs isolated by subcellular fractionation of fetal brain. Upon identifying 2 PKC substrates common to both 
GCPs and adult hippocampal formation, we used quantitative analysis of 2-dimensional gels to correlate the endogenous phosphorylation of these PKC substrates in adult hippocampus with the persistence of LTP.

\section{Materials and Methods}

Materials. All chemicals were analytical grade. Ultrapure urea was purchased from Schwarz-Mann. Tris (hydroxymethyl) aminomethane, acrylamide, and methylene bisacrylamide were from Polysciences. $\gamma^{-32} \mathrm{P}-$ ATP was obtained from ICN. Phosphatidylserine (PS) and protein standards for SDS-PAGE were supplied by Sigma. Staphylococcus aureus V8 protease was obtained from Miles Laboratories. Ampholytes, $40 \%$ of pH 3-10 were from Bio-Rad. Purified PKC and purified protein F1 were prepared as described previously (Murakami and Routtenberg, 1985; Chan et al., 1986).

Growth cone particles. GCPs were prepared as described previously (Pfenninger et al., 1983). Briefly, a low-speed supernatant from homogenate of 17-d gestation rat brain was layered onto a discontinuous sucrose gradient and spun to equilibrium $\left(248,000 \times g_{\max }\right.$ for $40 \mathrm{~min}$, $4^{\circ} \mathrm{C}$ ). The band at the load $/ 0.75 \mathrm{M}$ sucrose interface was collected, diluted, and centrifuged at $39,000 \times g$. This pellet $\left(\mathbf{P}_{1}\right.$, consisting of mostly broken GCPs) was resuspended in $50 \mathrm{~mm}$ Tris-HCL (pH 8.1).

Adult brain synaptosome-enriched fraction. A synaptosome-enriched fraction $\left(\mathrm{P}_{2}\right)$ was prepared as described previously (Conway and Routtenberg, 1978). Briefly, rat hippocampal formation was homogenized in $0.32 \mathrm{M}$ sucrose and centrifuged at $1000 \times g_{\max }$ for $10 \mathrm{~min}$. The supernatant was centrifuged a second time at $1000 \times g_{\max }$ and the second pellet also discarded. The second supernatant was centrifuged at 10,000 $\times g_{\max }$ for $20 \mathrm{~min}$, and the resulting pellet was washed by resuspension in $0.32 \mathrm{M}$ sucrose and centrifugation at $10,000 \times g_{\max }$ for $20 \mathrm{~min}$. This final pellet $\left(\mathrm{P}_{2}\right)$ was resuspended in buffers indicated in the individual figure captions.

Phosphorylation of tissue fractions in vitro. After protein determination (Lowry et al., 1951), all GCP, adult $\mathrm{P}_{2}$, or adult homogenate samples were adjusted to $2 \mathrm{mg} / \mathrm{ml}$ protein. Buffer containing all ions, chelating agents, and test substances for the final reaction conditions was added to each sample while on dry ice. In the case of experiments with PS or PKC, experimental and control samples were thawed on ice for $10 \mathrm{~min}$ in the presence of various concentrations of Triton X-100 (TX-100). To measure endogenous phosphorylation, samples were preincubated at $30^{\circ} \mathrm{C}$ for $45 \mathrm{sec}$, followed by incubation with $5 \mu \mathrm{M} \gamma{ }^{32} \mathrm{P}-$ ATP for $15 \mathrm{sec}$ in a final volume of $40 \mu \mathrm{l}$. Final reaction conditions are stated in text and figure captions. Quenching was by liquid nitrogen, followed by addition of $8.5 \mathrm{M}$ urea, $0.5 \% \mathrm{TX}-100$ (vol/vol), and $3 \%$ $\beta$-mercaptoethanol (vol/vol) for 2-dimensional separation. For separation by 1 -dimensional Laemmli gels $(5-15 \%$ acrylamide), samples were quenched by addition of $3 \times$ Laemmli sample buffer containing SDS (Laemmli, 1970). The resulting autoradiographs were analyzed by microdensitometry and computer integration of densitometric peaks (R. B. Nelson, D. J. Linden, and A. Routtenberg, unpublished observations).

Analysis by 2-dimensional gel electrophoresis (IEF-SDS). Two-dimensional electrophoresis by isoelectric focusing (IEF) and SDS molecular mass separation was performed according to O'Farrell (1975) with modifications described previously (Nelson and Routtenberg, 1985). Ten percent (wt/ $\mathrm{vol})$ polyacrylamide gels were used to separate protein in the second dimension, and in some cases gels were stained using a modification of the silver stain of Merril et al. (1981). Gels were dried and analyzed by autoradiography as described previously (Mitrius et al., 1981).

Levels of protein phosphorylation were determined by locating the proteins autoradiographically in the gels, excising the spots or bands, and counting directly without elution in a liquid scintillation spectrometer.

Analysis by nonequilibrium $p H$ gradient 2-dimensional gel electrophoresis (NEPHGE-SDS). The procedure for NEPHGE-SDS was essentially the same as that described by O'Farrell et al. (1977) with modifications described previously (Nelson and Routtenberg, 1985). Proteins were excised from NEPHGE-SDS gels and counted for ${ }^{32} \mathrm{P}$ incorporation as described in detail elsewhere (Nelson et al., 1987).

One-dimensional peptide mapping. Limited proteolysis using Staphylococcus aureus V8 protease was performed using a modification of the method of Cleveland et al. (1977). Briefly, proteins from dried, unstained 2-dimensional gels were located by autoradiography, excised, swollen in equilibration buffer, and loaded on a $15 \%$ acrylamide (wt/ vol) SDS-PAGE gel with a $3 \%$ acrylamide stacking gel $1 \mathrm{~cm}$ in length Excised protein slices were overlaid with $10 \mu \mathrm{g} S$. aureus V8 protease in a $10 \mu \mathrm{l}$ volume. Gels were electrophoresed at $50 \mathrm{~V}$ for $1 \mathrm{hr}$ (at which point the bromphenol blue tracking dye had entered the resolving gel), then at $160 \mathrm{~V}$ until the tracking dye reached the bottom of the gel. Electrophoresis was not interrupted at the stacking/resolving gel interface. Gels were then stained, dried, and processed for autoradiography.

Two-dimensional peptide mapping. An alternate procedure for limited proteolysis of proteins using $S$. aureus V8 protease, also derived from Cleveland et al. (1977), was used to prepare peptide fragments for separation by NEPHGE-SDS. Briefly, labeled protein spots containing F1 or pp46 from 2-dimensional gels were pooled, hydrated, macerated with a Teflon pestle, and eluted in distilled water for $24 \mathrm{hr}$ at $37^{\circ} \mathrm{C}$. The protein-containing supernatant was filtered, lyophilized, and resuspended in $334 \mu \mathrm{l} 20 \mu \mathrm{g} / \mathrm{ml}$ BSA added as carrier, then protein was precipitated by adding $60 \%$ TCA to a $20 \%$ final concentration (wt/vol). After washing twice with 1:2 ethanol/ether, the precipitate was resuspended in $0.125 \mathrm{M}$ Tris- $\mathrm{HCl}, \mathrm{pH} 7.2,10 \%$ glycerol, and $0.5 \% \mathrm{SDS}$, then incubated $1.5 \mathrm{hr}$ at $37^{\circ} \mathrm{C}$ in the presence of $0.2 \mathrm{mg} / \mathrm{ml} \mathrm{V} 8$ protease. After the reaction for 2-dimensional analysis was stopped as described above, peplide fragments were separated in 2 dimensions by use of $20 \%$ acrylamide $/ 2 \mathrm{mg} / \mathrm{ml}$ bis-acrylamide resolving gel in the second dimension. Gels were processed for autoradiography as described above.

In vivo long-term potentiation. 'The procedure for inducing LTP is described in detail elsewhere (Lovinger et al., 1986). Briefly, anesthetized animals were stimulated in the perforant path using 8 trains of eight $400 \mathrm{~Hz}$ pulses. The extracellular population spike was recorded from the hilus of the dentate gyrus 3 and $13 \mathrm{~min}$ following the high-frequency stimulation; the brains were then rapidly frozen in liquid nitrogen and stored at $-20^{\circ} \mathrm{C}$

The magnitude of spike potentiation (percentage of baseline spike amplitude, \% BSA) was calculated using the following formula:

(Spike amplitude after high-frequency stimulation at $t_{x} /$ Spike

amplitude before high-frequency stimulation) $\times 100$,

where $t_{x}=3$ or 13 min.

The persistence of spike potentiation was calculated as

$\left(\%\right.$ BSA at $\left.t_{13}-100\right) /\left(\%\right.$ BSA at $\left.t_{3}-100\right)$,

where $t_{3}$ and $t_{13}$ refer to 3 and $13 \mathrm{~min}$, respectively, following delivery of high-frequency stimulation.

\section{Results}

Proteins from a $\mathrm{P}_{2}$ fraction of adult rat hippocampal formation and from a GCP fraction were phosphorylated in vitro using $\gamma^{-32} \mathrm{P}-\mathrm{ATP}$ and separated in parallel by NEPHGE-SDS to compare endogenously labeled phosphoproteins in the 2 preparations (Fig. 1). As reported previously, there are striking differences in the relative incorporation of phosphoproteins between these 2 preparations (Katz et al., 1985). In GCPs, only 4 major phosphoproteins were detectable, in contrast to 20 or more in adult $P_{2}$. Although many other phosphoproteins were detectable on longer exposure of the GCP autoradiograms, their incorporation was at least 10 -fold lower than that of the 4 major phosphoproteins. The most highly labeled phosphoprotein was pp46 (\#3), followed in order by pp80 (\#2), pp40 (\#4), and a grouping of proteins that might correspond to phosphorylated tubulin. ${ }^{4}$ Note that synapsin Ia and Ib (\#1), among the most prominent phosphoproteins in adult $\mathrm{P}_{2}{ }^{\prime}$, are only minor components in GCPs (Katz et al., 1985).

In order to identify PKC substrates in adult $P_{2}$ and GCPs, we added exogenous, purified PKC to the 2 preparations in the

\footnotetext{
${ }^{4}$ The fourth major phosphoprotein(s) on the 2-dimensional gels are probably $\alpha$ - and $\beta$-tubulin based on their molecular mass, isoelectric point, and partial insolubility (manifested as "streaking") on the gels.
} 
pI:

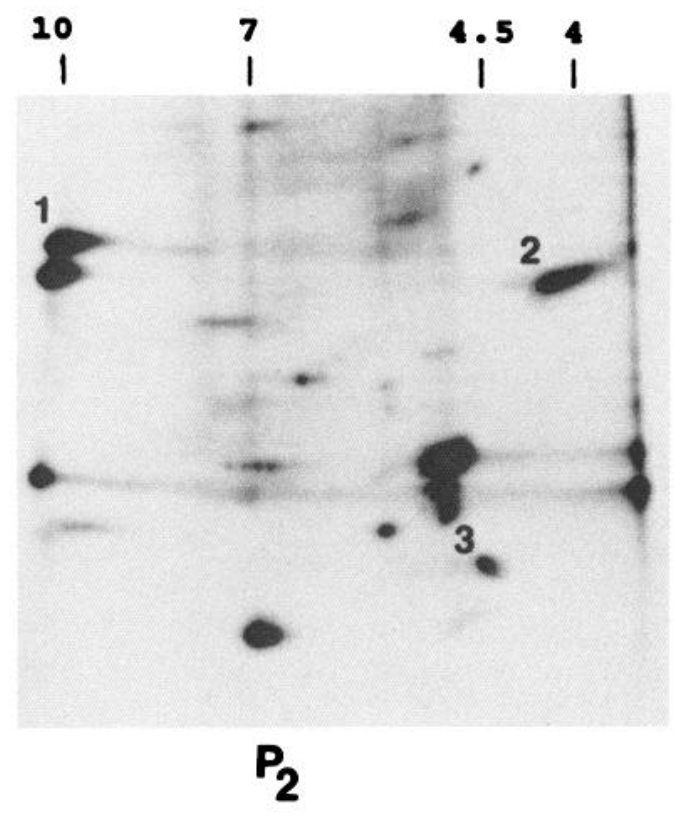

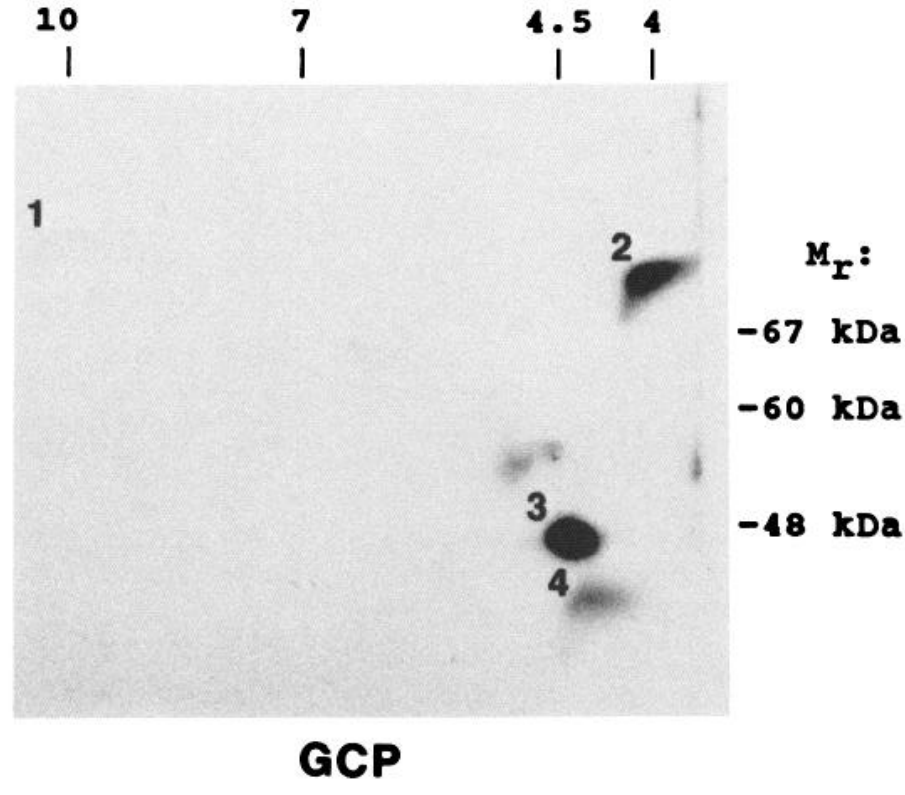

Figure 1. Autoradiographs comparing ${ }^{32} \mathrm{P}$-labeled phosphoproteins from $\mathrm{P}_{2}$ and GCPs. Phosphoproteins from a $\mathrm{P}_{2}$ fraction of adult rat hippocampal formation and from GCPs were separated by NEPHGE-SDS (see Materials and Methods). Samples were reacted with $\gamma^{-32} \mathrm{P}-\mathrm{ATP}$ (see Materials

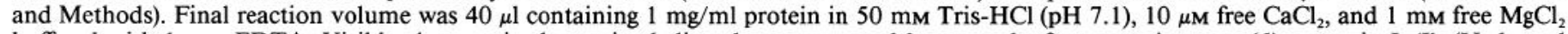
buffered with $1 \mathrm{~mm}$ EDTA. Visible characterized proteins believed to correspond between the 2 preparations are $(I)$ synapsin Ia/Ib (Ueda and Greengard, 1977; Nestler and Greengard, 1986), which are clearly seen only upon longer exposure in GCPs; (2) $80 \mathrm{k}$ in adult $\mathrm{P}_{2}$ and pp80 in GCPs (Wu et al., 1982; Katz et al., 1985; Blackshear et al., 1986); (3) protein F1 in adult $\mathrm{P}_{2}$ and pp46 in GCPs; (4) pp40 in GCPs (Katz et al., 1985), normally barely detectable in adult preparations. Autoradiographs were exposed for different times to give comparable development of the PKC substrates (number 2, 3, and 4) in each autoradiograph. Protein 4 labeling (pp40) was not detectable among $\mathrm{P}_{2}$ proteins even on longer exposure of the autoradiograph. Baseline cpm values for proteins were as follows: F1, 3241; pp46, 59995; 80k, 9619; pp80, 51782. Autoradiographs are representative of several comparisons.

presence of $300 \mu \mathrm{M} \mathrm{Ca}{ }^{2+5}$. We found a dose-dependent increase in phosphorylation of pp46, pp 80 , and pp40 in GCPs (Table 1). Thus, 3 of the 4 major phosphoproteins detected in GCPs were PKC substrates. In the adult hippocampal $\mathrm{P}_{2}$ fraction, $\mathrm{PKC}$

\footnotetext{
${ }^{5}$ Maximal activation rate of purified PKC phosphorylating purified protein in F1 occurs at a concentration near $200 \mu \mathrm{M} \mathrm{Ca}{ }^{2+}$ and $100 \mu \mathrm{g} / \mathrm{ml}$ PS (Chan et al.,
} 1986). stimulated the phosphorylation of 2 proteins termed protein $\mathrm{F} 1$ and $80 \mathrm{k}$, but this stimulation was limited and did not increase steadily with increasing PKC concentration (Table 1). A factor in adult rat brain that inhibits PKC activity has recently been discovered (Chan et al., 1985). Since this inhibitory factor is removed by ammonium sulfate precipitation (Chan et al., 1985), we prepared such an inhibitor-free fraction from rat brain $\mathrm{P}_{2}$,

Table 1. Stimulation of ${ }^{32} \mathrm{P}$ incorporation into selected proteins by exogenous purified PKC

\begin{tabular}{llllllll}
$\begin{array}{l}\text { Added } \\
\text { PKC } \\
\text { (pmol/ } \\
\text { min) }\end{array}$ & $\begin{array}{l}\text { F1 } \\
\text { from P2 }\end{array}$ & $\begin{array}{l}\text { 80k } \\
\text { from P2 }\end{array}$ & $\begin{array}{l}\text { F1 from } \\
\text { ASP 40-80 }\end{array}$ & $\begin{array}{l}\text { 80k from } \\
\text { ASP 40-80 }\end{array}$ & $\begin{array}{l}\text { pp46 } \\
\text { from GCPs }\end{array}$ & $\begin{array}{l}\text { pp80 } \\
\text { from GCPs }\end{array}$ & $\begin{array}{l}\text { pp40 } \\
\text { from }\end{array}$ \\
\hline 0 & 100 & 100 & 100 & ND & 100 & 100 & 100 \\
1 & 111 & 60 & 193 & ND & 133 & 168 & 147 \\
5 & 102 & 67 & 592 & 100 & 150 & 233 & 224 \\
10 & 101 & 107 & 1139 & 375 & 297 & 344 & 361 \\
50 & 155 & 226 & 3777 & 933 & 619 & 898 & 917 \\
100 & 154 & 384 & 6696 & 2487 & 818 & 1432 & 1479
\end{tabular}

${ }^{32} \mathrm{P}$ incorporation into proteins was measured by liquid scintillation spectrometry of protein spots cut from 2-dimensional gels (see Materials and Methods). Stimulation of incorporation by added PKC is expressed as a percentage of control values. ND, not detectable above background. PKC activity is expressed as picomoles $\mathrm{P}_{\mathrm{i}}$ incorporated into histone per minute $(\mathrm{pmol} / \mathrm{min})$. Final reaction concentrations were $1 \mathrm{mg} / \mathrm{ml}$ protein in $50 \mathrm{~mm}$ Tris- $\mathrm{HCl}(\mathrm{pH} 7.1), 0.1 \%$ TX-100, $300 \mu \mathrm{M} \mathrm{Ca}{ }^{2+}$ free, $1 \mathrm{mM} \mathrm{Mg}^{2+}$ free, buffered with $1 \mathrm{~mm}$ EDTA. Incubation with $5 \mu \mathrm{M} \gamma-{ }^{32} \mathrm{P}-\mathrm{ATP}$ was as described in Figure 1. Purified PKC having a specific activity of $1460 \mathrm{nmol} \mathrm{P}_{\mathrm{i}} / \mathrm{min} \mathrm{mg}$ histone was prepared as previously described (Murakami and Routtenberg, 1985). "F1 from $\mathrm{P}_{2}$ " and " $80 \mathrm{k}$ from $\mathrm{P}_{2}$ " were both cut from the same 2-dimensional gels of $\mathrm{P}_{2}$ proteins. ASP 40-80 was a 1-step purification of $\mathrm{F} 1$ from a pH extract of $\mathrm{P}_{2}$ proteins by 40 and $80 \%$ ammonium sulfate precipitation followed by dialysis against $50 \mathrm{~mm}$ Tris- $\mathrm{HCl}(\mathrm{pH} 7.1)$. This fraction was then phosphorylated under the conditions listed above with the inclusion of $50 \mu \mathrm{g} / \mathrm{ml}$ of PS and separated on 2-dimensional gels. Phosphorylation of $80 \mathrm{k}$ protein was detectable in this fraction after a minimal addition of $5 \mathrm{pmol} / \mathrm{min}$ of PKC activity. This level of phosphorylation was then used as a baseline for addition of higher PKC concentrations. "pp46 from GCPs," "pp80 from GCPs," and "pp40 from GCPs" were all cut from the same 2-dimensional separations of phosphorylated GCP proteins. Experiments were performed twice. Values shown are from one experiment. 
Figure 2. Comigration and similar microheterogeneity on 2-dimensional autoradiographs of phosphorylated protein $F 1$ versus pp 46 , and $80 \mathrm{k}$ versus $\mathrm{pp} 80$. Proteins adjusted to $1 \mathrm{mg} / \mathrm{ml}$ concentration were labeled by endogenous phosphorylation as in Figure 1 and separated by IEF-SDS (see Materials and Methods). Protein $\mathrm{F} 1$ in $\mathrm{P}_{2}$ and pp46 in GCPs are indicated by arrows. $80 \mathrm{k}$ in $\mathrm{P}_{2}, \mathrm{pp} 80$ and pp40 in GCPs are indicated by arrowheads. The exposure times of the autoradiographs were adjusted to give similar intensities of protein $\mathrm{F} 1$ and $\mathrm{pp} 46$. Baseline cpm values for proteins were as follows: F1, 2197; pp46, 33005; 80k, 1641; pp80, 30294. Autoradiographs are representative of several comparisons.
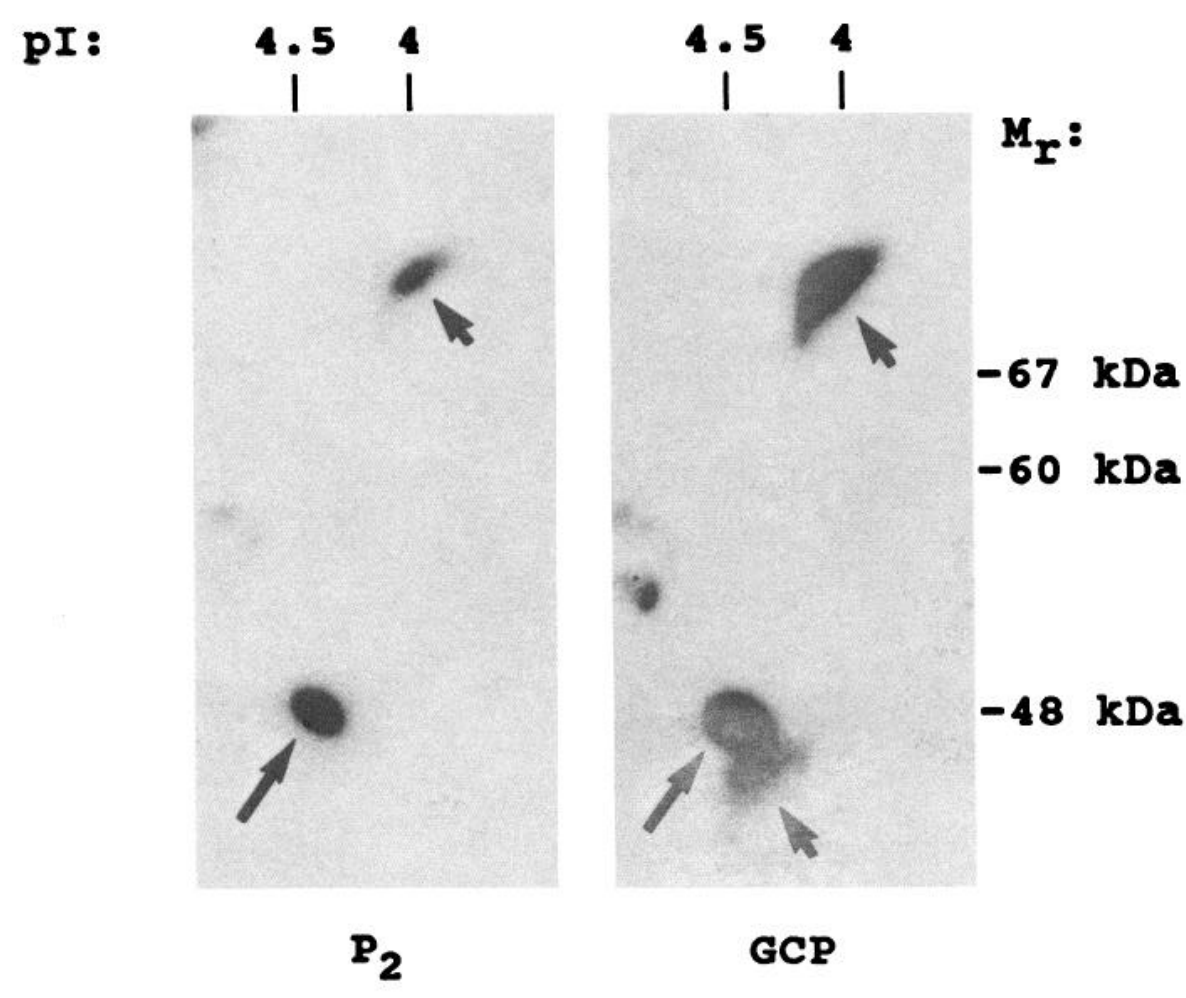

then added increasing concentrations of PKC to the fraction in the presence of $50 \mu \mathrm{g} / \mathrm{ml}$ PS. In this preparation, a dose-dependent stimulation of protein $\mathrm{F} 1$ and $80 \mathrm{k}$ phosphorylation by exogenous, purified PKC was found (Table 1). The large percentage increase in phosphorylation obtained following addition of PKC to this fraction is partly due to removal of most of the endogenous PKC activity following ammonium sulfate precipitation, so that basal phosphorylation of protein $\mathrm{Fl}$ and $80 \mathrm{k}$ is extremely low.

Whereas a protein potentially corresponding to pp40 was detectable only on prolonged exposure in the adult $\mathrm{P}_{2}$ preparation, 2 relatively well-labeled phosphoproteins termed protein $F 1$ and $80 \mathrm{k}$ in adult rat brain comigrated with the GCP phosphoproteins termed pp46 and pp80, respectively (Fig. 2). Under the gel conditions used, protein $\mathrm{F} 1$ and pp46 exhibited an apparent molecular mass of $47 \mathrm{kDa}^{6}$ and an isoelectric point of 4.5 . Both proteins also exhibited a slight, but characteristic charge heterogeneity, with a slightly higher molecular mass at the alkaline end. This microheterogeneity is more apparent in silver stains of protein F1 and pp46 (Fig. 3); 80k and pp80 had an apparent molecular mass of $78-80 \mathrm{kDa}$ and an isoelectric point of 4.0 . These 2 proteins shared a distinctive charge heterogeneity with a higher molecular weight at the acidic end and a "trail" of label in the molecular mass dimension at the alkaline end. This distinctive microheterogeneity is also apparent in the silver stain of pp80 in Figure 3; however, 80k was not detectable in the silver stain. Because equal amounts of protein were loaded onto the gels shown in Figure 3, the relative stain densities of proteins

${ }^{6}$ Óbservations from several laboratories, including our own, indicate that F1/ pp46 migrates anomalously on SDS-PAGE gels with regard to molecular mass standards. The apparent molecular mass of $\mathrm{F} 1 / \mathrm{pp} 46$ decreases with increasing percentage polyacrylamide gels. Thus, it was important in the present study to compare protein F1 and pp46 separated in parallel on the same gel system. indicate qualitative enrichment of pp46 and pp80 in GCPs versus protein $\mathrm{F} 1$ and $80 \mathrm{k}$ in $\mathrm{P}_{2}$.

The 4 phosphoproteins were further compared by subjecting each to peptide mapping following limited proteolysis with $S$. aureus V8 protease (Fig. 4). On a 1-dimensional separation, 3 phosphopeptide bands were generated under these conditions from protein F1 and pp46: 2 major bands at 11 and $13 \mathrm{kDa}$, and a minor band at $23 \mathrm{kDa}$. When these same proteolytic fragments were further compared by separation in 2 dimensions, an extensive heterogeneity was revealed within the 11 and 13 $\mathrm{kDa}$ bands of both proteins, while the $23 \mathrm{kDa}$ band appeared as a single acidic peptide. On 2-dimensional peptide maps, protein F1 and pp46 have at least 10 phosphopeptide spots in common. Protein F1 and pp46 thus appear to be highly homologous, if not identical, on the basis of these maps. ${ }^{7}$

Two-dimensional phosphopeptide maps of $80 \mathrm{k}$ and pp80 yielded 2 bands of peptides at 12 and $14 \mathrm{kDa}$ (Fig. 4). In contrast to protein F1 and pp46, the pattern on these maps was 3 closely spaced, poorly resolved peptides of basic $\mathrm{pH}$ within each band. An aberration in the migration front of these peptides was seen in the area of highest label incorporation. This aberration was reproducible and appears to be due to some property inherent in the peptides that disturbs their migration on SDS gels. ${ }^{8} 80 \mathrm{k}$ and pp 80 appear to be highly similar, if not identical, on the basis of these maps.

\footnotetext{
Small differences in the phosphopeptide pattern on these maps (particularly in minor phosphopeptides) appears to be due to minor differences in the degree of proteolysis rather than differences in substrate cleavage sites since these minor differences are not consistent. In side experiments to explore this issue, we performed parallel digestions on identical proteins from the same preparation and still obtained minor differences in phosphopeptide patterns.

${ }^{8}$ Recent evidence suggests that $80 \mathrm{k} / \mathrm{pp} 80$ (and pp40) both covalently bind fatty acids (Perrone-Bizzozero et al., 1987). Charge masking by fatty acids might explain both the poor resolution of $80 \mathrm{k} / \mathrm{pp} 80$ peptide fragments in the isoelectrofocusing dimension and the characteristic aberration produced in the migration front of the SDS dimension.
} 
Because protein F1, pp46, 80k, and pp80 could be phosphorylated by exogenous PKC, we characterized the endogenous PKC activity in adult hippocampal $\mathrm{P}_{2}$ and fetal brain GCPs. Under the same basal phosphorylation conditions (no addition of kinase stimulators) with protein adjusted to $1 \mathrm{mg} / \mathrm{ml}$, the endogenous phosphorylation of pp46 and pp80 in GCPs was typically 15-20 times higher than that of protein F1 and $80 \mathrm{k}$ in adult hippocampal $\mathrm{P}_{2}$ (measured as $\mathrm{cpm}$ of ${ }^{32} \mathrm{P}$-incorporation into protein spots; see Figs. 1 and 2 legends). In contrast, overall kinase activity was lower in GCPs as measured by TCA precipitation of total protein, being $60 \%$ of the incorporation found in hippocampal $\mathrm{P}_{2}$. Although part of this increased phosphorylation of pp46 and pp80 in GCPs relative to protein F1 and $80 \mathrm{k}$ in $\mathrm{P}_{2}$ would be due to the enrichment of these proteins in GCPs (Fig. 3), the short in vitro reaction time used favors detection of differences in kinase activity over differences in substrate concentration (Matus et al., 1980). It is therefore likely that the higher endogenous phosphorylation of pp46 and pp80 also represents higher activity of the kinase phosphorylating these proteins.

As expected for endogenous PKC activity, addition of PS stimulated the phosphorylation of both pp46 and protein F1 in a dose-dependent manner; however, PS was only moderately effective in increasing the phosphorylation of pp 80 and $80 \mathrm{k}$ (Fig. $5)$. We have found $80 \mathrm{k}$ phosphorylation to be highly stimulated by PS in a synaptosomal cytosol fraction (R. B. Nelson and A. Routtenberg, unpublished observations), similar to $\mathrm{Wu}$ et al. (1982); however, these studies used soluble fractions separated from membrane, as did a report finding a large PS stimulation of pp80 (Katz et al., 1985). We have also previously seen PS inhibition of $80 \mathrm{k}$ phosphorylation in a membrane preparation under the same conditions that protein $\mathrm{F} 1$ phosphorylation was stimulated (a $0.05 \%$ TX-100-containing $\mathrm{P}_{2}$ ' preparation; Nelson and Routtenberg, 1985). It appears, then, that the presence or absence of membrane elements, as well as the concentration of detergent added, is critical in determining relative stimulation of protein phosphorylation following addition of phospholipids. During the course of these experiments, we also discovered that the concentration of added detergent at which PS stimulation of protein $\mathrm{F} 1$ and pp46 is obtained is different between $\mathrm{P}_{2}$ and GCPs. At a $0.05 \%$ final concentration of TX-100, for example, phosphorylation of pp46 was inhibited by added PS, while protein F1 phosphorylation was stimulated. This discrepancy most likely reflects differences in the lipid environment of GCPs versus $\mathrm{P}_{2}$ since a high lipid-to-protein ratio has been found in GCP membranes (Sbaschnig-Agler et al., 1988).

The second major PKC substrate, $80 \mathrm{k}$, described here in both adult $\mathrm{P}_{2}$ and GCPs, is masked in adult $\mathrm{P}_{2}$ by comigration on 1-dimensional gels with the major phosphoproteins synapsin Ia and $\mathrm{Ib}$ (see Fig. 1). In order to determine whether phosphorylation of $80 \mathrm{k}$ is also correlated with persistence of LTP (as previously reported for protein F1), we used 2-dimensional electrophoresis (NEPHGE-SDS) to separate ${ }^{32} \mathrm{P}$-labeled dorsal hippocampal proteins from 17 animals receiving high-frequency stimulation and determined incorporation into protein spots by liquid scintillation. The phosphorylation of both protein F1 and $80 \mathrm{k}$ was directly correlated with persistence of LTP $13 \mathrm{~min}$ after the delivery of the potentiating stimulation (Fig. 6). When the same samples were separated on 1-dimensional gels by molecular mass alone, only the correlation of protein F1 to persistence of LTP was detected (data not shown), in agreement with previous reports (Routtenberg et al., 1985; Lovinger et al., 1986).

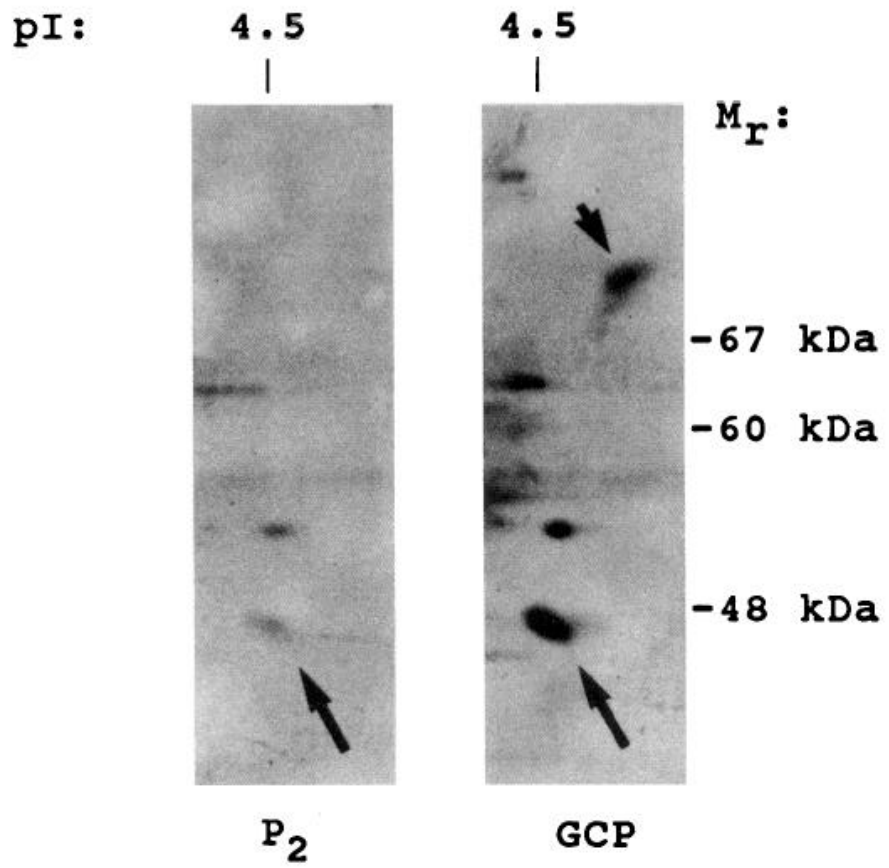

Figure 3. Enrichment of pp 46 and pp80 in GCPs versus protein $\mathrm{F} 1$ and $80 \mathrm{k}$ in $\mathrm{P}_{2}$, and similar microheterogeneity in pp46 and protein $\mathrm{F} 1$ from 2-dimensional silver-stained gels. $P_{2}$ fraction and GCPs were separated by IEF-SDS as in Figure 2. Arrows indicate $\mathrm{F} 1$ in $\mathrm{P}_{2}$ and pp46 in GCPs. Arrowhead indicates pp 80 in GCPs. Staining of $80 \mathrm{k}$ in $\mathrm{P}_{2}$ was below detection level. In both cases, $25 \mu \mathrm{g}$ of total protein was loaded on the gels. Gels were stained as described in Materials and Methods.

\section{Discussion}

Activity of PKC has been implicated in both neurite outgrowth and in the persistence of LTP. In the present report, PKC substrates were compared between a fraction of purified growth cone particles from fetal rat brain (GCPs) and a synaptosomeenriched fraction of hippocampal formation from adult rat brain. We detected 4 major phosphoproteins from GCPs having ${ }^{32} \mathrm{P}$ incorporation levels at least 10 -fold greater than other phosphoproteins in the GCP fraction (Fig. 1). Of these 4 phosphoproteins, the 3 termed pp80, pp46, and pp40 (Katz et al., 1985; Hyman and Pfenninger, 1987) were all phosphorylated by exogenously added PKC, suggesting that PKC plays a central role relative to other protein kinases in growth cone function. These 3 phosphoproteins also appear to be the same as the 3 major phorbol ester stimulated phosphoproteins in a primary neuronal cell culture (Burgess et al., 1986).

Although immunochemical and amino acid sequence data are presently available only for protein Fl (Rosenthal et al., 1987), the present evidence strongly suggests that pp46 and pp80, the 2 highest endogenously phosphorylated substrates detected in GCPs (Fig. 1), are identical to protein F1 and $80 \mathrm{k}$, respectively, 2 acidic phosphoproteins in adult rat hippocampal formation. This identification is made on the basis of similar molecular mass, isoelectric point, charge heterogeneity, and 2-dimensional phosphopeptide mapping of these proteins when examined in parallel in the same gel system. In addition, both proteins in GCPs responded similarly to their counterparts in adult hippocampal $\mathrm{P}_{2}$ with regard to phosphorylation by exogenous PKC and in their response to the addition of the endogenous PKC stimulators $\mathrm{Ca}^{2+}$ and PS. Increased phosphor- 

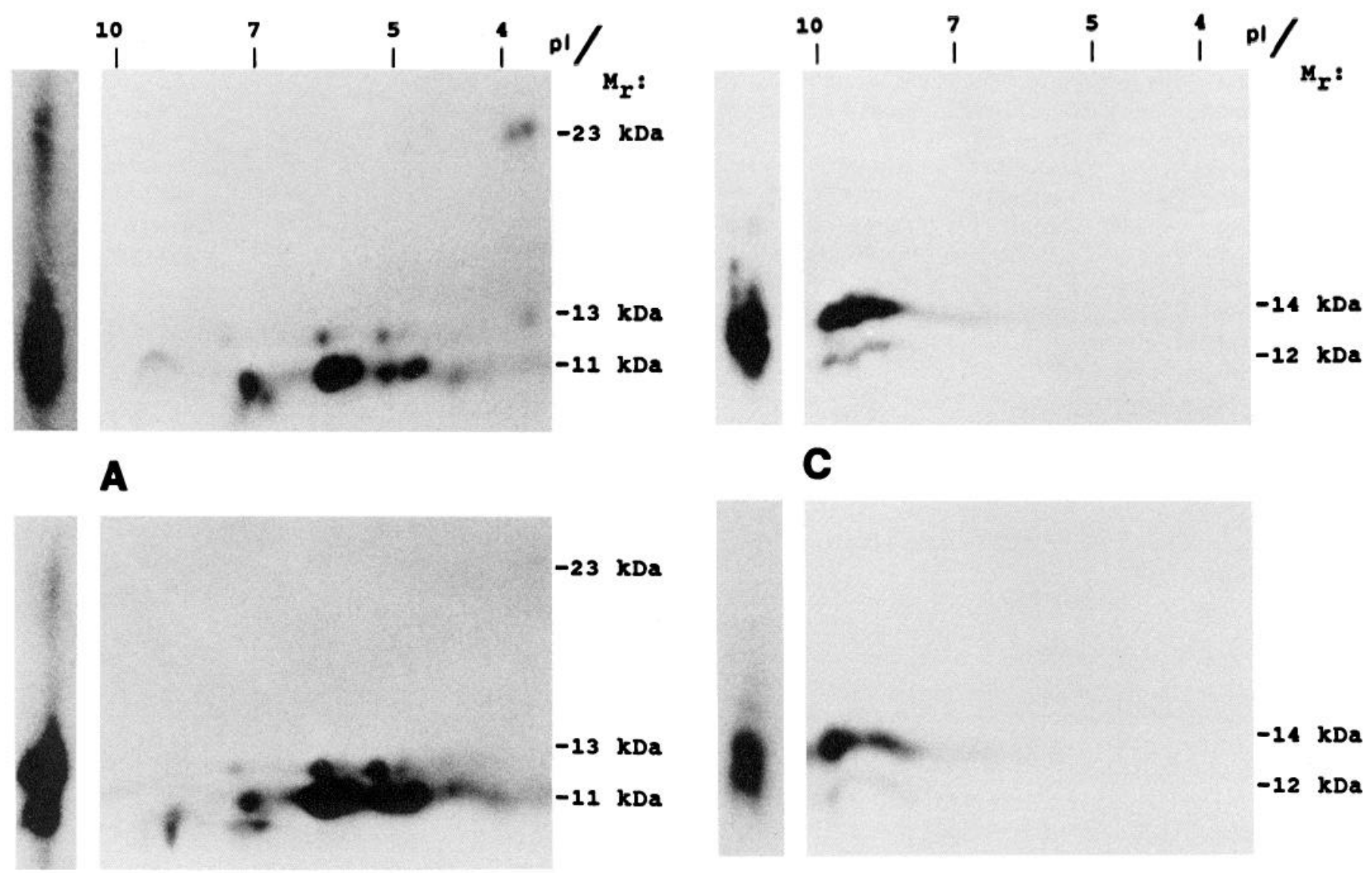

B

Figure 4. Phosphopeptide maps of GCP and $\mathrm{P}_{2}$ proteins following limited proteolysis by $S$. aureus $\mathrm{V} 8$ protease. Endogenously labeled proteins were harvested from 2-dimensional gels and were prepared for analysis on 1-or 2-dimensional gels as described in Materials and Methods. In each case, a 1-dimensional separation of phosphopeptides is shown in a lane at left, and a 2-dimensional NEPHGE-SDS separation of the same phosphopeptides is shown at right: $A$, protein $\mathrm{F} 1$ from $\mathrm{P}_{2} ; B$, pp46 from GCPs; $C, 80 \mathrm{k}$ from $\mathrm{P}_{2} ; D$, pp 80 from GCPs. Autoradiographs are representative of several comparisons.

ylation of pp46, pp80, protein $\mathrm{F} 1$, and $80 \mathrm{k}$ in the presence of PKC-stimulating phorbol esters has also been found (Hyman and Pfenninger, 1987; R. B. Nelson, D. J. Linden, and A. Routtenberg, unpublished observations).

With regard to other kinase systems, a moderate stimulation of pp46 phosphorylation $(\sim 20 \%)$ in the presence of exogenous calmodulin $(\mathrm{CaM})$ and high $\mathrm{Ca}^{2+}$ has been reported (Katz et al., 1985). In contrast to PKC, however, $3 \mathrm{Ca}^{2+} / \mathrm{CaM}$-stimulated kinases tested to date have failed to phosphorylate purified protein F1 (Chan et al., 1986). It is possible, then, that the CaM effect on $\mathrm{F} 1 / \mathrm{pp} 46$ phosphorylation does not occur directly through a $\mathrm{Ca}^{2+} / \mathrm{CaM}$-stimulated kinase. Addition of cAMP does not increase phosphorylation of pp46 or protein F1 (Conway and Routtenberg, 1978; Ellis et al., 1985), nor is purified protein F1 phosphorylated by exogenous cAMP-dependent kinase (Chan et al., 1986).

Phosphorylation of protein $\mathrm{F} 1, \mathrm{pp} 46,80 \mathrm{k}$, and pp80 could all be stimulated in a dose-dependent manner by exogenous purified PKC (Table 1); however, this increase was dose dependent for the adult brain proteins only after a pH extract of $\mathrm{P}_{2}$ proteins was precipitated between 40 and $80 \%$ saturation with ammonium sulfate. This treatment removes a PKC inhibitory factor (Chan et al., 1985). Such PKC inhibitory factors have been described previously (Albert et al., 1984; Schwantke and LePeuch, 1984; McDonald and Walsh, 1985). Interestingly, the growth cone preparation required no such treatment for PKC stimulation to be dose dependent, suggesting that the PKC inhibitory factor is absent or present in much lower concentrations in the growth cone preparation and may thus be developmentally regulated. The lack of this inhibitory factor may also account in part for the high endogenous levels of PKC substrate phosphorylation found in the growth cone preparation. Recently, purified protein F1 has been shown to be a high-affinity substrate for purified PKC (Chan et al., 1986), as has a purified protein believed to be the same as $80 \mathrm{k}$ and pp80 (Wu et al., 1982; Blackshear et al., 1986). These findings strengthen the notion that $\mathrm{F} 1 / \mathrm{pp} 46$ and $80 \mathrm{k} / \mathrm{pp} 80$ are physiological substrates for PKC.

Protein F1 and pp46 were both stimulated by addition of PS in the presence of low $\mathrm{Ca}^{2+}$ and $\mathrm{TX}-100$, but the percentage stimulation was higher for protein F1 (Fig. 5). This may have been due to the already high basal kinase activity found in growth cones, i.e., PS-stimulated kinase activity may be near maximal activation. A related possibility is that pp46 might be close to saturation with unlabeled phosphate groups, leading to a lack of available unphosphorylated substrate during the in 
vitro assay. pp 80 phosphorylation and $80 \mathrm{k}$ were only moderately stimulated by addition of PS in the current study (Fig. $5 B$ ). Although both of these proteins have been strongly stimulated by addition of PS in previous studies (Wu et al., 1982; Katz et al., 1985; R. B. Nelson and A. Routtenberg, unpublished ıobservations), those studies measured $80 \mathrm{k}$ and pp 80 phosphorylation in soluble fractions with no membrane present, in contrast to the present study. Since PS itself is a membrane component, it is likely that the presence of other membrane elements in the phosphorylation assay make PS of limited use in showing quantitative stimulation of PKC in membrane-containing samples.

Using quantitative analysis of 2-dimensional gels, we found in the present study that the in vitro phosphorylation of $80 \mathrm{k}$ in adult dorsal hippocampus was directly correlated to the persistence over $10 \mathrm{~min}$ of LTP induced in vivo (Fig. 6). This experiment also replicated a direct correlation of protein $F 1$ with the persistence of LTP. When the same experimental samples were separated by 1-dimensional SDS-PAGE alone, only the correlation of protcin F1 to persistencc of LTP was detectable, indicating that the effect on $80 \mathrm{k}$ is masked by its comigration with the major phosphoprotein doublet found in adult brain, synapsin Ia and Ib.

These results indicate, first, that protein $\mathrm{F} 1$ is not unique among PKC substrates in being correlated with persistence of LTP and, instead, suggest that the neural PKC system is important for relating PKC activity to adult synaptic plasticity. Because recent reports indicate that changes in PKC activity are a cause, rather than a consequence, of changes in persistence in LTP (Routtenberg et al., 1986; Linden et al., 1987; Lovinger et al., 1987), determining the functional roles of these different neural PKC substrates is now a key question in understanding the biochemical mechanisms underlying LTP.

The phosphorylation of protein F1/pp 46 and $80 \mathrm{k} / \mathrm{pp} 80$ paralleled each other in the present study both with regard to their relationship to persistence of LTP and their enrichment in GCPs. Previously, both proteins were also shown to exhibit gradients of ${ }^{32} \mathrm{P}$ incorporation along the occipitotemporal visual processing pathway in rhesus monkey cerebral cortex (Nelson et al., 1987). These gradients peak in medial temporal areas important for storage of visual recognition memory.

There are also contrasts in the characteristics of protein $\mathrm{F} 1 /$ pp 46 versus $80 \mathrm{k} / \mathrm{pp} 80$, in which $80 \mathrm{k} / \mathrm{pp} 80$ behaves as both an integral membrane protein and a soluble protein during subcellular fractionation (Albert et al., 1986), whereas protein F1/ pp46 has only been found in membrane-associated fractions (Zwiers et al., 1980; Skene and Willard, 1981c; Katz et al., 1985; Nelson and Routtenberg, 1985; Simkowitz et al., 1989). Moreover, protein F1/pp46, as the B-50 protein (Gispen et al., 1986), is thought to be brain-specific and presynaptically localized (Kristjansson et al., 1982; Gispen et al., 1985), while 80k/pp80 appears to have a widespread distribution among tissues and species (Albert et al., 1986), similar to that of PKC (Kuo et al., 1980). Protein F1/pp46 has recently been coidentified with GAP43 (Skene and Willard, 1981a-c; Benowitz and Lewis, 1983; Meiri et al., 1986; Snipes et al., 1987), a protein whose synthesis is greatly increased following nerve crush or axotomy. No such changes in synthesis during regeneration have been reported for $80 \mathrm{k} / \mathrm{pp} 80$. Finally, $80 \mathrm{k} / \mathrm{pp} 80$ was rccently reported to be covalently bound to myristic acid (Perrone-Bizzozero et

${ }^{9}$ Both GAP43 and B-50 have been reported to be present in purified growth cone preparations (De Graan et al., 1985; Meiri et al., 1986; Skene et al., 1986).
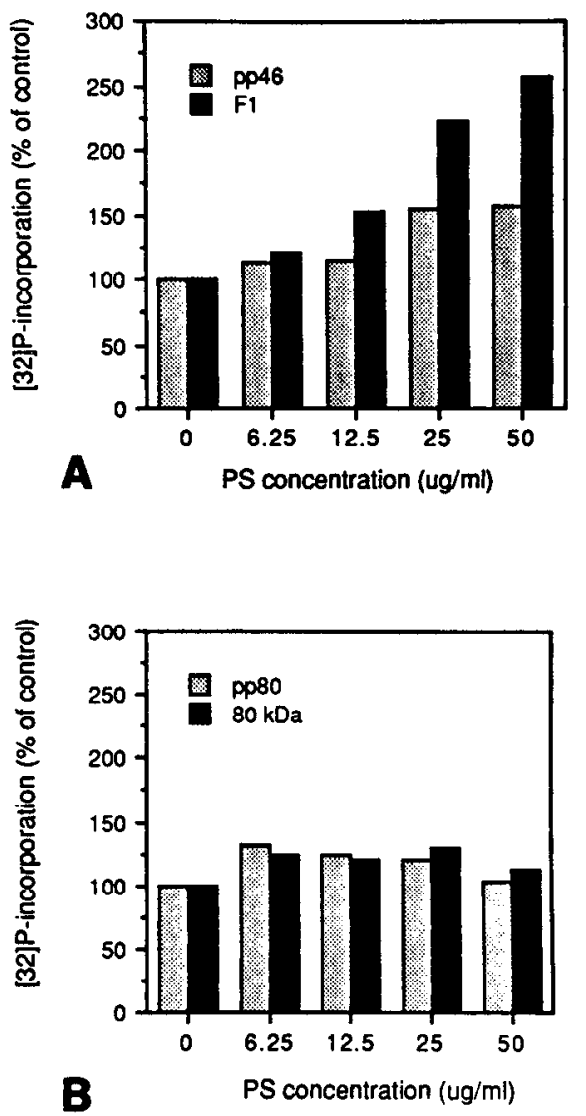

Figure 5. Effects of exogenous PS on ${ }^{32} \mathrm{P}$ incorporation into $(A)$ protein $\mathrm{Fl}$ and pp 46 and $(B) 80 \mathrm{kDa}$ and pp80. Aliquots from a common source $\left(\mathrm{P}_{2}\right.$ or GCPs) were incubated on ice in the presence of $0.15 \% \mathrm{TX}-100$ for $10 \mathrm{~min}$. Duplicate samples were incubated with increasing concentrations of PS as indicated. Final reaction conditions were the same as in Figure 1 except that samples contained a final concentration of $0.075 \%$ TX-100. Labeled proteins were excised from 2-dimensional gels using the autoradiograph as a guide and counted for radioactive phosphate as described in Materials and Methods. Comparison shows the percentage of stimulation from control levels. Each value is an average of 2 determinations.

al., 1987), whereas protein F1/pp46 does not appear to have this posttranslational modification.

F1/pp46 and $80 \mathrm{k} / \mathrm{pp} 80$ were moderately labeled proteins among 20 or more major phosphoproteins detected in adult hippocampus, but were the 2 highest endogenously labeled phosphoproteins detected in the growth cone-enriched preparation (Fig. 1). It is intriguing to ask what role these major growth cone phosphoproteins might have in the neuropil of mature CNS. Since the phosphorylation of both of these proteins is related to persistence of LTP (Fig. 6), one hypothesis is that adult neural plasticity as modelled by LTP may involve molecular mechanisms employed during nervous system development, i.e., neurite growth. If such were the case, the appearance of LTP might require either restructuring of adult synapses or possibly terminal sprouting and the formation of new synapses (Routtenberg, 1985, 1986; Ptenninger, 1986; Pfenninger et al., 1986). Changes in synapse morphology of hippocampal neurons following induction of LTP has been observed (Lee et al., 1980; Desmond and Levy, 1983; Greenough, 1984). Such a model of neural plasticity was proposed as a basis for information storage several decades ago (Hebb, 1949).

The present findings make it attractive to propose that a com- 

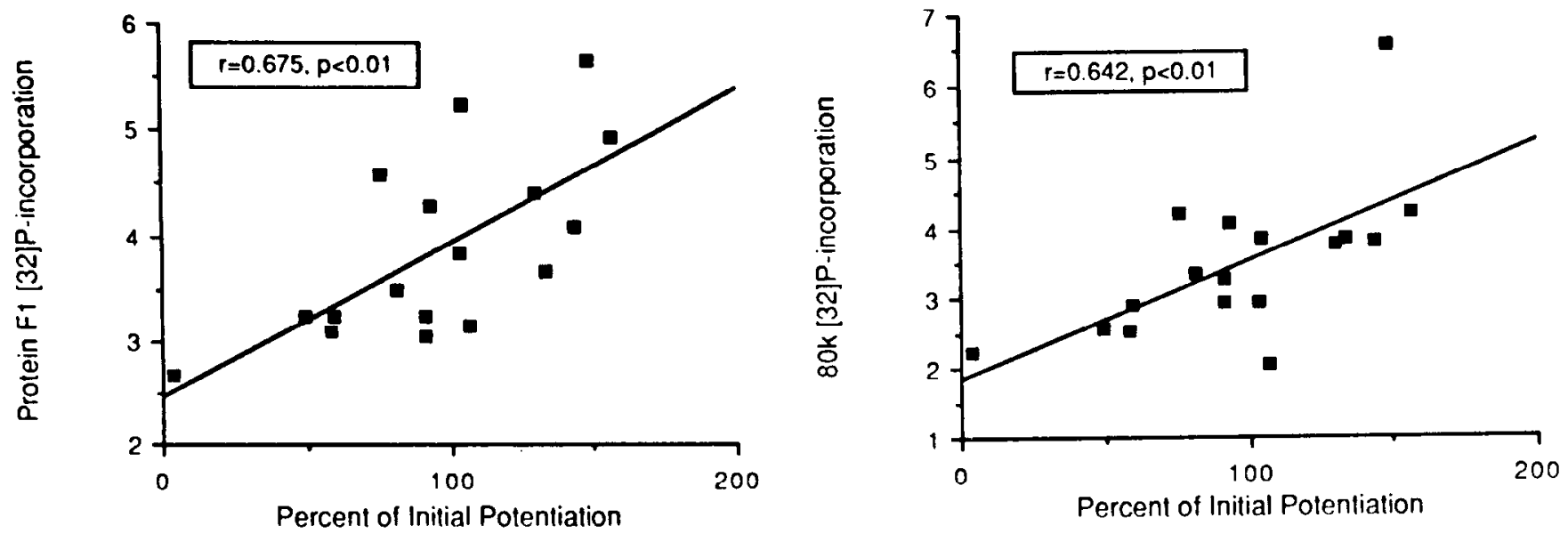

Figure 6. Scatterplots comparing in vitro phosphorylation of protein $F 1 / \mathrm{pp} 46$ and $80 \mathrm{k} / \mathrm{pp} 80$ in adult rat dorsal hippocampal formation with persistence of initial potentiation remaining in the population spike amplitude after 10 min. The units on the abscissa are cpm $\times 10^{3}$, while the percentage on the ordinate is a measure of persistence of spike amplitude; e.g., 100\% would mean the increase in spike amplitude following highfrequency stimulation did not change from 3 to $13 \mathrm{~min}, 200 \%$ would mean the increase in spike amplitude doubled over that time, and $0 \%$ would mean the increase in spike amplitude decayed back to the prestimulation baseline during that time. Each point is derived from an individual test animal. ${ }^{32}$ P-labeled proteins from each of 17 LTP test animals were separated by NEPHGE-SDS, excised from the gels, and then counted by liquid scintillation (see Materials and Methods). The reaction with $\gamma_{-32}{ }^{32}$-ATP is described in Materials and Methods. The final reaction volume was 40 $\mu \mathrm{l}$ containing $1 \mathrm{mg} / \mathrm{ml}$ protein, $5 \mu \mathrm{M} \gamma^{-32}$-ATP $(100 \mu \mathrm{Ci}), 30 \mathrm{~mm}$ potassium phosphate (pH 7.1), $2 \mathrm{~mm} \mathrm{Mg}^{2+}, 1 \mathrm{~mm}$ EDTA, and $1 \mathrm{~mm}$ DTT.

mon molecular mechanism - involving F1/pp $46,80 \mathrm{k} / \mathrm{pp} 80$, and PKC-may underlie both normal neurite growth in developing brain and neural plasticity of adult synapses.

\section{References}

Akers, R. F., and A. Routtenberg (1985) Kinase C phosphorylates a protein involved in synaptic plasticity. Brain Res. 334: 147-151

Akers, R. F., D. Lovinger, P. Colley, D. Linden, and A. Routtenberg (1986) Translocation of protein kinase $C$ activity may mediate hippocampal long term potentiation. Science 231: 587-589.

Albert, K. A., W. C. S. Wu, A. C. Nairn, and P. Greengard (1984) Inhibition by calmodulin of calcium/phospholipid-dependent protein phosphorylation. Proc. Natl. Acad. Sci. USA 81: 3622-3625.

Albert, K. A., S. I. Walaas, J. K. T. Wang, and P. Greengard (1986) Widespread occurrence of " $87 \mathrm{kDa}$," a major specific substrate for protein kinase C. Proc. Natl. Acad. Sci. USA 83: 2822-2826.

Benowitz, L. I., and E. R. Lewis (1983) Increased transport of 44,000to 49,000-dalton acidic proteins during regeneration of the goldfish optic nerve: A two-dimensional gel analysis. J. Neurosci. 3: 21532163.

Blackshear, P. J., L. Wen, B. P. Glynn, and I. A. Witters (1986) Protein kinase $\mathrm{C}$-stimulated phosphorylation in response to phorbol esters and growth factors in intact fibroblasts. J. Biol. Chem. 261: 14591469 .

Bliss, T. V. P., and T. Lomo (1973) Long lasting potentiation of synaptic transmission in the dentate area of the anesthetized rabbit following stimulation of the perforant path. J. Physiol. (Lond.) 232: 357-374.

Burgess, S. K., N. Sahyoun, S. G. Blanchard, H. LeVine III, K. J. Chang, and $P$. Cuatrecasas (1986) Phorbol ester receptors and protein kinase $\mathrm{C}$ in primary neuronal cultures: Development and stimulation of endogenous phosphorylation. J. Cell Biol. 102: 312-319.

Castagna, M., Y. Takai, K. Kaibuchi, K. Sano, U. Kikkawa, and Y. Nishizuka (1982) Direct activation of calcium-activated, phospholipid-dependent protein kinase by tumor-promoting phorbol esters. J. Biol. Chem. 257: 7847-7851.

Chan, S. Y., K. Murakami, and A. Routtenberg (1985) Purification of a kinase $C$ substrate: Brain phosphoprotein $F 1$ and an endogenous kinase C inhibitory factor. Soc. Neurosci. Abstr. 11: 926.

Chan, S. Y., K. Murakami, and A. Routtenberg (1986) Phosphoprotein F1: Purification and characterization of a brain kinase $\mathrm{C}$ substrate related to plasticity. J. Neurosci. 6: 3618-3627.

Cleveland, D. W., S. G. Fischer, M. W. Kirschner, and U. K. Laemmli
(1977) Peptide mapping by limited proteolysis in sodium dodecyl sulfate and analysis by gel electrophoresis. J. Biol. Chem. 252: 11021106.

Conway, R. G., and A. Routtenberg (1978) Endogenous phosphorylation in vitro: Selective effects of sacrifice methods on electrophoretically separated protein bands. Brain Res. 139: 366-373.

De Graan, P. N. E., C. O. M. Van Hooff, B. C. Tilly, A. B. Oestricher, P. Schotman, and W. H. Gispen (1985) Phosphoprotein B-50 in nerve growth cones from fetal rat brain. Neurosci. Lett. 8: 235-241.

Desmond, N. L., and W. B. Levy (1983) Synaptic correlates of associative potentiation/depression: An ultrastructural study in the hippocampus. Brain Res. 265: 21-30.

Ellis, L., F. Katz, and K. H. Pfenninger (1985) Nerve growth cones isolated from fetal rat brain: II. Cyclic adenosine $3^{\prime}: 5^{\prime}$-monophosphate (cAMP)-binding proteins and cAMP-dependent protein phosphorylation. J. Neurosci. 5: 1393-1401.

Gispen, W. H., J. L. M. Leunissen, A. B. Oestreicher, A. J. Verkleij, and $\mathrm{H}$. Zwiers (1985) Presynaptic localization of B-50 phosphoprotein: The (ACTH)-sensitive protein kinase substrate involved in rat brain polyphosphoinositide metabolism. Brain Res. 328: 381385 .

Gispen, W. H., P. N. E. De Graan, S. Y. Chan, and A. Routtenberg (1986) Comparison between the neural acidic proteins $B 50$ and $F 1$ Prog. Brain Res. 69: 383-386.

Greenough, W. T. (1984) Structural correlates of information storage in the mammalian brain: $\Lambda$ review and hypothesis. Trends Biochem. Sci. 7: 229-233.

Hebb, D. O. (1949) The Organization of Behavior, p. 335, Wiley, New York.

Hsu, L., D. Natyzak, and J. D. Laskin (1984) Effects of the tumor promoter 12-0-tetradecanoylphorbol-13-acetate on neurite outgrowth from chick embryonic sensory ganglia. Cancer Res. 44: 46074614.

Hyman, C., and K. H. Pfenninger (1987) Intracellular regulators of neuronal sprouting: II. Phosphorylation reactions in isolated growth cones. J. Neurosci. 7: 4076-4083.

Katz, F., L. Ellis, and K. H. Pfenninger (1985) Nerve growth cones isolated from fetal rat brain: Calcium-dependent protein phosphorylation. J. Neurosci. 5: 1402-1411.

Kikkawa, U., Y. Takai, R. Minakuchi, S. Inohara, and Y. Nishizuka (1982) Calcium-activated, phospholipid-dependent protein kinase from rat brain. J. Biol. Chem 257: 13341-13348.

Kraft, A. S., and W. B. Andersen (1983) Phorbol esters increase the amount of calcium, phospholipid-dependent protein kinase associated with the plasma membrane. Nature 301: 621-623. 
Kristjansson, G. I., H. Zwiers, A. B. Oestricher, and W. H. Gispen (1982) Evidence that the synaptic phosphoprotein B50 is localized exclusively in nerve tissue. J. Neurochem. 39: 371-378.

Kuo, J. F., R. G. G. Andersson, B. B. Wise, L. Mackerlova, I. Salomonsson, N. L. Brackett, N. Katoh, and R. W. Wrenn (1980) Calcium dependent protein kinase: Widespread occurrence in various tissues and phyla of the animal kingdom and comparison of effects of phospholipid, calmodulin, and trifluoperazine. Proc. Natl. Acad. Sci. USA 77: 7039-7043.

Laemmli, U. K. (1970) Cleavage of structural proteins during the assembly of bacteriophage T4. Nature 227: 680-685.

Lee, K. S., F. Schottler, M. Oliver, and G. Lynch (1980) Brief bursts of high-frequency stimulation produce two types of structural change in rat hippocampus. J. Neurophysiol. 44: 247-258.

Linden, D. J., F. -S. Sheu, K. Murakami, and A. Routtenberg (1987) Enhancement of long-term potentiation by cis-unsaturated fatty acid: Relationship to protein kinase $\mathrm{C}$ and phospholipase $\mathrm{A}_{2}$. J. Neurosci. 7: 3783-3792.

Lovinger, D. M., R. F. Akers, R. B. Nelson, C. A. Barnes, B. L. McNaughton, and A. Routtenberg (1985) A selective increase in the phosphorylation of protein $\mathrm{F} 1$, a protein kinase $\mathrm{C}$ substrate, directly related to three day growth of long-term synaptic enhancement. Brain Res. 343: 137-143.

Lovinger, D. M., P. A. Colley, R. F. Akers, R. B. Nelson, and A. Routtenberg (1986) Direct relation of long-duration synaptic potentiation to phosphorylation of membrane protein Fl: A substrate for membrane protein kinase C. Brain Res. 339: 205-211.

Lovinger, D. M., K. L. Wong, K. Murakami, and A. Routtenberg (1987) Protein kinase $\mathrm{C}$ inhibitors eliminate hippocampal long-term potentiation. Brain Res. 436: 177-183

Lowry, O., N. J. Rosebrough, and R. J. Randall (1951) Protein measurement with the Folin phenol reagent. J. Biol. Chem. 193: 265275.

Matus, A. I., M. L. Ng, and J. P. Mazat (1980) Protein phosphorylation in synaptic membranes: Problems of interpretation. In Protein Phosphorylation and Bio-Regulation, G. Thomas, E. J. Podesta, and J. Gorson, eds., pp. 25-36, Karger, Basel.

McDonald, J. R., and M. P. Walsh (1985) $\mathrm{Ca}^{+}$-binding protein from bovine brain including a potent inhibitor of protein kinase C. Biochem. J. 232: 559-567.

Meiri, K. F., K. H. Pfenninger, and M. B. Willard (1986) Growthassociated protein, GAP-43, a polypeptide that is induced when neurons extend axons, is a component of growth cones and corresponds to pp46, a major polypeptide of a subcellular fraction enriched in growth cones. Proc. Natl. Acad. Sci. USA 83: 3537-3541.

Merril, C. R., D. Goldman, S. A. Sedman, and M. H. Ebert (1981) Ultrasensitive stain for proteins in polyacrylamide gels shows regional variation in cerebrospinal fluid proteins. Science 211: 1437-1438.

Mitrius, J. C., D. G. Morgan, and A. Routtenberg (1981) In vivo phosphorylation following ${ }^{32} \mathbf{P}$-orthophosphate injection into neostriatum or hippocampus: Selective and rapid labelling of electrophoretically-separated proteins. Brain Res. 212: 67-81.

Murakami, K., and A. Routtenberg (1985) Direct activation of purified protein kinase $\mathrm{C}$ by unsaturated fatty acids (oleate and arachidonate) in the absence of phospholipids and $\mathrm{Ca}^{++}$. FEBS Lett. 192: 189-193.

Murphy, K. M. M., R. J. Gould, M. L. Oster-Granite, J. D. Gearheart, and S. H. Snyder (1983) Phorbol ester receptors: Autoradiographic identification in the developing rat. Science 222: 1036-1038.

Nagle, D. S., S. Jake, M. Castagna, and P. M. Blumberg (1981) Variation with embryonic development and regional localization of specific $\left[{ }^{3} \mathrm{H}\right]$ phorbol 12,13-dibutyrate binding to brain. Cancer Res. 41 : $89-93$.

Natyzak, L. H. D., and J. D. Laskin (1984) Effects of the tumor promoter 12-o-tetradecanoylphorbol-13-acetate on neurite outgrowth from chick embryo sensory ganglia. Cancer Res. 44: 46074614.

Nelson, R. B., and A. Routtenberg (1985) Characterization of the 47kD protein $\mathrm{F} 1$ (pI 4.5), a kinase $\mathrm{C}$ substrate directly related to neural plasticity. Exp. Neurol. 89: 213-224.

Nelson, R. B., D. P. Friedman, J. B. O'Neill, M. Mishkin, and A. Routtenberg (1987) Gradients of protein kinase C substrate phosphorylation in primate visual system peak in visual memory storage areas. Brain Res. 416: 387-392.
Nestler, E. J., and P. Greengard (1986) Synapsin I: A review of its distribution and biological regulation. Brain Res. 69: 323-340.

Niedel, J. F., I. J. Kuhn, and G. R. Vandenbark (1983) Phorbol diester receptor copurifies with protein kinase C. Proc. Natl. Acad. Sci. USA 80:36-40.

O'Farrell, P. H. (1975) High resolution two-dimensional electrophoresis of proteins. J. Biol. Chem. 250: 4007-4021.

O'Farrell, P. Z., H. M. Goodman, and P. H. O'Farrell (1977) High resolution two-dimensional electrophoresis of basic as well as acidic proteins. Cell 12: 1133-1142.

Perrone-Bizzozero, N. I., P. J. Apostolides, S. P. Finklestein, L. I. Benowitz, and O. Bizzozero (1987) Soc. Neurosci. Abstr. 17: 1478.

Pfenninger, K. H. (1986) Of nerve growth cones, leukocytes and memory: Second messenger systems and growth-regulated proteins. Trends Neurosci. 9: 562-565.

Pfenninger, K. H., L. Ellis, M. P. Johnson, L. B. Friedman, and S. Somlo (1983) Nerve growth cones isolated from fetal rat brain. I. Subcellular fractionation and characterization. Cell 35: 573-584.

Pfenninger, K. H., C. Hyman, and R. S. Garofalo (1986) Protein phosphorylation in the nerve growth cone. Prog. Brain Res. 69: 235244.

Rosenthal, A., S. Y. Chan, W. Henzel, C. Haskell, W. J. Kuang, E. Chen, J. N. Wilcox, A. Ullrich, D. V. Goeddel, and A. Routtenberg (1987) Primary structure and mRNA localization of protein $\mathrm{Fl}$, a growthrelated protein kinase $C$ substrate associated with synaptic plasticity. EMBO 6: $3641-3646$

Routtenberg, A. (1985) Protein kinase C activation leading to protein F1 phosphorylation may regulate synaptic plasticity by presynaptic terminal growth. Behav. Neural Biol. 44: 186-200.

Routtenberg, A. (1986) Synaptic plasticity and protein kinase C. Prog. Brain Res. 69: 211-234.

Routtenberg, A., D. M. Lovinger, and O. Steward (1985) Selective increase in the phosphorylation of a $47 \mathrm{kD}$ protein (F1) directly related to long-term potentiation. Behav. Neural Biol. 43: 3-11.

Routtenberg, A., P. Colley, D. Linden, D. Lovinger, K. Murakami, and F. S. Sheu (1986) Phorbol ester promotes growth of synaptic plasticity. Brain Res. 378: 374-378.

Sbaschnig-Agler, M., K. H. Pfenninger, and R. W. Ledeen (1988) Gangliosides and other lipids of the growth cone membrane. J. Neurochem. 51: 212-220.

Schwantke, N., and C. J. Le Peuch (1984) A protein kinase C inhibitory activity is present in rat brain homogenate. FEBS Lett. 177: 36-40.

Simkowitz, P., L. Ellis, and K. H. Pfenninger (1989) Membrane proteins of the nerve growth cone and their developmental regulation. J. Neurosci. (in press).

Skene, J. H. P., and M. Willard (1981a) Changes in axonally transported proteins during axon regeneration in toad retinal ganglion cells. J. Cell Biol. 89: 86-95.

Skene, J. H. P., and M. Willard (1981b) Axonally transported proteins associated with axon growth in rabbit central and peripheral nervous system. J. Cell Biol. 89: 96-103.

Skene, J. H. P., and M. Willard (1981c) Characteristics of growthassociated polypeptides in regenerating toad retinal ganglion cell axons. J. Neurosci. 1: 419-426.

Skene, J. H. P., R. D. Jacobson, G. J. Snipes, C. B. McGuire, J. J. Norden, and J. A. Freeman (1986) A protein induced during nerve growth (GAP-43) is a major component of growth cone membranes. Science 233: 783-785.

Snipes, J., S. Chan, C. B. McGuire, B. R. Costello, J. J. Norden, J. A. Freeman, and A. Routtenberg (1987) Evidence for the co-identification of GAP-43, a growth-associated protein, and F1, a plasticityassociated protein. J. Neurosci. 7: 4066-4075.

Ueda, T., and P. Greengard (1977) Adenosine $3^{\prime}: 5^{\prime}$ monophosphateregulated phosphoprotein system of neuronal membranes. I. Solubilization, purification, and some properties of an endogenous phosphoprotein. J. Biol. Chem. 252: 5155-5163.

Wu, W. C., S. I. Walaas, A. C. Nairn, and P. Greengard (1982) Calcium/phospholipid regulates phosphorylation of a Mr " $87 \mathrm{k}$ " substrate protein in brain synaptosomes. Proc. Natl. Acad. Sci. USA 79: 52495253.

Zwiers, H., P. Schotman, and W. H. Gispen (1980) Purification and some characteristics of an ACTH-sensitive protein kinase and its substrate protein in rat brain membranes. J. Neurochem. 33: 247256. 